\title{
The Level Of Knowledge And Prevention Of Overtraining In The Province Level Basketball Team
}

\author{
Siti Rahmawati Ardila ${ }^{1}$, Muhammad Fadhlurrohman Akmal $^{1}$, Gigih Siantoro ${ }^{1}$, Donny Ardi \\ Kusuma $^{1}$, Abdul Hafidz ${ }^{1}$, Kunjung Ashadi ${ }^{1}$ \\ \{siti.17060474018@mhs.unesa.ac.id ${ }^{1}$,muhammad.18060474013@mhs.unesa.ac.id², \\ gigihsiantoro@unesa.ac.id $\left.{ }^{3}\right\}$ \\ Universitas Negeri Surabaya, Surabaya, Indonesia ${ }^{1}$
}

\begin{abstract}
The purpose of this study was to determine the level of knowledge and prevention of overtraining at the provincial level basketball team. The method uses quantitative and descriptive. The research targets were 12 female basketball athletes and 2 coaches who participated in Regional Training Center. Data obtained through surveys using multiple choice questions and questionnaires. The analysis technique used the mean, percentage, normality test, and difference test with SPSS 25 . The results showed the average knowledge value of athletes was 84.6 (very good) and the prevention of overtraining that had been applied by athletes was 56.41 (fair). Meanwhile, the average value of the coach's knowledge was 80 (good) and the prevention of overtraining that had been applied by the coaches was 75.64 (good). The conclusion shows that there is a significant difference between knowledge and prevention of athletes $(\mathrm{p}<0.05)$, but there is no significant difference in coaches ( $\mathrm{p}>0.05)$.
\end{abstract}

Keywords: Knowledge, prevention, overtraining, athletes, coaches.

\section{Introduction}

The facts show that to achieve optimal performance must go through a good sports coaching system. One of them is structured training [1]. Thus, the level of education and knowledge of athletes and coaches about overtraining greatly affects the training process. It is reinforced by the opinion of Ashadi [2] that factors that can affect optimal sports performance and achievement include athletes and coaches, knowledge and personality, facilities and infrastructure, competition situations, and science related to sports training. So it is important for coaches to always improve their knowledge and skills related to sports training they are engaged in. Because the coach's role is very important in the success of a team, namely in making training programs, managing the training process, and helping athletes prepare for maximum performance.

Thus athletes must do intensive training for a long period, to achieve maximum performance. Of course, doing intensive training regularly also prioritizes exercise to improve physical condition and training of technical skills simultaneously by giving weight gradually. Both of these exercises, if done without paying attention to the ability of an athlete's body, especially when doing physical exercise, can trigger fatigue and have an impact on the athlete's technical performance [3]. 
Excessive exercise without thinking about the recovery period can be risky poor condition for athletes, namely experiencing decreased performance due to fatigue in training [4]. In exercise physiology, the term used to describe the incidence of excessive exercise that is not balanced with adequate rest is called overtraining [5]. Overtraining is not only caused by overtraining. [6] Carter et al, argue that overtraining is also caused by an inadequate recovery period, lack of good nutritional intake, poor sleep quality, excessive emotional stress in the environment, work and psychology, and lack of communication between athletes and coaches. So that it can disrupt in the body's work system [7].

Disorders that can be experienced due to overtraining are different signs or symptoms for each athlete. [8] Grivas research supports the statement that symptoms of overtraining appear more than $60 \%$ in distance runners during their athletic career, and more than $50 \%$ during 5 months of the season in professional football players, and symptoms of overtraining occur in $33 \%$ for basketball players, underwent 6 weeks of training. Symptoms that arise can hurt the athlete's physical or psychological condition. If it is not handled quickly in the right way, it will have a negative impact on the condition of the athlete.

The impact of overtraining is that it causes chronic fatigue, decreased immunity, increased stress hormones, muscle pain so that you are prone to injury [9]. It is reinforced by the results of Kenta's 2015 research on 628 athletes in Sweden, showing that athletes who experience injuries are caused by or overtraining. even Overtraining can occur reach $20-30 \%$ with the more serious cases. So that the athlete's career is at stake, what is worse, athletes can experience early retirement from sports due to overtraining.

Therefore, athletes and coaches need to carry out prevention strategies overtraining an optimal. Because preventing disease is better than cure, especially in cases of overtraining. [6] Carter et al state that there are six best methods to prevent overtraining which include : making an appropriate exercise program; monitoring exercise and recovery; have good sleep quality; adequate water and good nutrition; have good communication between athletes and coaches; education or education about overtraining. Based on the description above, athletes and coaches must know and understand about overtraining, be it about the causes, symptoms that arise, and the impact that will occur. By knowing and understanding this, athletes and coaches can apply prevention overtraining. Therefore, athletes and coaches who have good knowledge about overtraining will also apply prevention overtraining properly.

The problem that exists is the limited literature of research results that show the fact of the level of knowledge about overtraining in athletes and coaches. Therefore, this research is important as follow-up research. The novelty in this study lies in the characteristic aspects of the subject, namely the provincial level athletes and basketball coaches, as well as measuring the level of prevention of overtraining. The results between the knowledge value and the prevention of overtraining will be compared to whether there is a difference or not.

This research was conducted as a rationale for further research or policy-making for basketball athletes and coaches throughout Indonesia regarding efforts to identify and understand the dangers of overtraining, to implement prevention strategies overtraining. By having good knowledge and prevention of overtraining, it is hoped that this will be a positive step in achieving an optimal sports achievement. 


\section{Methods}

This study used a descriptive design and survey test methods. The research target is the basketball team at the provincial level. The respondents who participated were 12 female athletes and 2 coaches. The subject criteria are athletes and basketball coaches who are active in participating in the Regional Training Center.

The instrument used in this study is multiple-choice questions to determine the level of knowledge of overtraining, as well as using questionnaires to know the level of prevention of overtraining. The questionnaire has passed the validity and reliability test with the athlete's value (0.985) (0.979) and coach (0.961) (0.962). The questionnaire consists of 39 questions using the Guttman scale. Questionnaire indicators can be seen in the following table.

Table 1. Indicator questionnaire

\begin{tabular}{ll}
\hline Question Number & Indicator Questionnaire \\
\hline $1-8$ & Periodization \\
$9-15$ & Exercise Monitoring \& Recovery \\
$16-23$ & Sleep \\
$24-35$ & Hydration \& Nutrition \\
$36-38$ & Communication \\
39 & Education \\
\hline
\end{tabular}

The data collection technique was carried out in an online survey using Google Form. Distributing the link prevention questionnaire to respondents via the group WhatsApp is one of the methods of collecting data for this research. After the questionnaire data was collected, the knowledge data collection was continued using multiple-choice questions totaling 25 questions. Retrieval of knowledge data, namely through video conferencing individually per respondent, with the application Zoom or Google Meet to assist in displaying questions and answer choices, as well as being able to find out which respondents answered honestly without any help from others.

The research data collection period was carried out in December 2020. After all, data was collected, it was analyzed by calculating the mean, percentage, normality test, different tests using the Independent T-test on normally distributed data, and the Maan-Whitney test on abnormally distributed data with the help of SPSS. version 25.

\section{Results}

After researching an online survey in the form of multiple-choice questions and a questionnaire using Google Form, the following results can be obtained. The profile data of research subjects is shown in Figure 1.

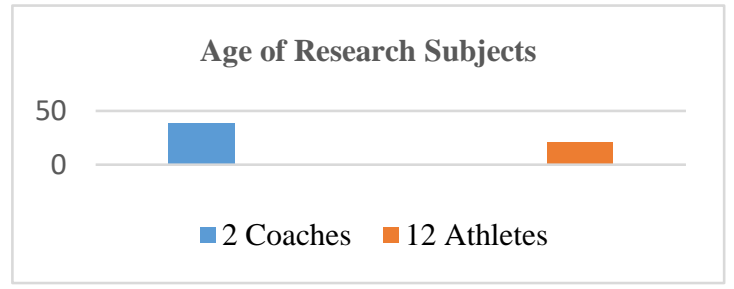


Fig. 1. Age of research subjects

Based on the data in Figure 1, it can be seen that the average age of the two coaches is 39 years. While the average age of the 12 athletes is 20.6 years.

Table 2. Educational background of research subjects

\begin{tabular}{cccc}
\hline No & Name & Position & Educational Background \\
\hline 1 & LN & Coach & Senior High School \\
2 & IWT & Coach & Senior High School \\
3 & SK & Athletes & S1 \\
4 & JH & Athletes & S1 \\
5 & JSN & Athletes & S1 \\
6 & ACW & Athletes & S1 \\
7 & FI & Athletes & S1 \\
8 & FS & Athletes & S1 \\
9 & ARA & Athletes & S1 \\
10 & DKP & Athletes & S1 \\
11 & FAS & Athletes & S2 \\
12 & MP & Athletes & Senior High School \\
13 & JE & Athletes & \\
14 & EK & Athletes &
\end{tabular}

Based on the data in table 2 it can be seen that the last education of the two coaches was high school graduation. Meanwhile, of the 12 athletes, there is 1 athlete with high school education and 11 other athletes who have a university education, either S1 or S2.

The following is the calculation result of data analysis for multiple-choice questions about overtraining. The results of the knowledge value of athletes and coaches about overtraining are shown in the following table.

Table 3. Results of athlete's knowledge value about overtraining

\begin{tabular}{llll}
\hline Range of Values & Category & Frequency $(\mathrm{n})$ & $\%$ \\
\hline $81-100$ & Very Good & 9 & $75 \%$ \\
$61-80$ & Good & 3 & $25 \%$ \\
$41-60$ & Fair & 0 & 0 \\
$21-40$ & Less & 0 & 0 \\
$0-20$ & Very Poor & 0 & 0 \\
\hline Average Value & 84.67 (Very Good) & & \\
\hline
\end{tabular}

The data shows that most of the athletes' knowledge results are in the very good category with a percentage of $75 \%$. Only $25 \%$ in either category. Based on the data in table 3 , it can be concluded that the average value of athletes' knowledge about overtraining is 84.67 in the very good category.

Table 4. Results of coach's knowledge value about overtraining

\begin{tabular}{llll}
\hline Range of Values & Category & Frequency $(\mathrm{n})$ & $\%$ \\
\hline $81-100$ & Very Good & 1 & $50 \%$ \\
$61-80$ & Good & 1 & $50 \%$ \\
$41-60$ & Fair & 0 & 0 \\
\hline
\end{tabular}




\begin{tabular}{lccc}
\hline $21-40$ & Poor & 0 & 0 \\
$0-20$ & Very Poor & 0 & 0 \\
\hline & Average Value & & $80(\mathrm{Good})$ \\
\hline
\end{tabular}

The data shows that the results of the coach's knowledge are $50 \%$ in the very good category and $50 \%$ in the good category. Based on the data in table 4, it can be concluded that the average value of the coach's knowledge of overtraining is 80 in the good category.

Based on the data in table 3 and table 4 , it can be concluded that the level of knowledge of overtraining in athletes and coaches is very good. This is very positive because with good knowledge it is hoped that athletes and coaches will also have prevention overtraining good.

Table 5. Prevention values results of overtraining in athletes

\begin{tabular}{llll}
\hline Range of Values & Category & Frequency $(\mathrm{n})$ & $\%$ \\
\hline $81-100$ & Very Good & 0 & 0 \\
$61-80$ & Good & 6 & $50 \%$ \\
$41-60$ & Fair & 5 & $41.7 \%$ \\
$21-40$ & Less & 1 & $8.3 \%$ \\
$0-20$ & Very Poor & 0 & 0 \\
\hline \multicolumn{4}{c}{ Average Value } \\
\hline
\end{tabular}

Table 5 shows that most of the results of prevention of overtraining athletes are in the good and adequate category with a percentage of $50 \%$ and $41.7 \%$. Only $8.3 \%$ in the poor category. Based on the data in table 5 , it can be concluded that the average value for preventing overtraining for athletes is 56.41 in the fair category.

Table 6. Prevention of values for the overtraining in coaches

\begin{tabular}{llll}
\hline Range of Values & Categories & Frequency $(\mathrm{n})$ & $\%$ \\
\hline $81-100$ & Very Good & 0 & 0 \\
$61-80$ & Good & 2 & $100 \%$ \\
$41-60$ & Fair & 0 & 0 \\
$21-40$ & Less & 0 & 0 \\
$0-20$ & Very Poor & 0 & 0 \\
\hline \multicolumn{2}{l}{ Average Value } & & 75.64 (Good) \\
\hline
\end{tabular}

Table 6 shows that the results of the prevention of overtraining are coach $100 \%$ in the good category. Based on the data in table 6 , it can be concluded that the average prevention value of overtraining coaches 75.64 in the good category.

The prevention questionnaire was overtraining divided into 6 strategy groups, namely periodization, monitoring of exercise and recovery, sleep, hydration and nutrition, communication, and education. From the six groups, 39 questions were made. The results of the prevention strategies overtraining that have been implemented by athletes and coaches can be seen in the following table.

Table 7. Prevention of overtraining in athletes based on strategies

\begin{tabular}{lll}
\hline for Preventing Strategies Overtraining & Percentage (\%) & Category \\
\hline Periodization & $87.5 \%$ & Very Good \\
Exercise Monitoring \& Recovery & $57.29 \%$ & Fair \\
\hline
\end{tabular}




\begin{tabular}{lll}
\hline Sleep & $40.47 \%$ & Less \\
Hydration \& Nutrition & $46.52 \%$ & Fair \\
Communication & $47,22 \%$ & Fair \\
Education & $58.33 \%$ & Fair \\
\hline
\end{tabular}

Based on the data in table 7, it can be seen that athletes have implemented a prevention strategy with the periodization method of $87.5 \%$ in the very good category, training monitoring and recovery of $57.29 \%$ in the fair category, sleeping $40.47 \%$ in the less category, hydration and nutrition $46.52 \%$ are in the fair category, communication $47.22 \%$ are in the fair category, and education $58.33 \%$ are in the fair category.

Table 8. Prevention of overtraining in coaches based on their

\begin{tabular}{lll}
\hline Methods Prevention Methods of Overtraining & Percentage (\%) & Category \\
\hline Periodization & $100 \%$ & Very Good \\
Exercise Monitoring \& Recovery & $81.3 \%$ & Very Good \\
Sleep & $64.29 \%$ & Good \\
Hydration \& Nutrition & $54.17 \%$ & Fair \\
Communication & $100 \%$ & Very Good \\
Education & $100 \%$ & Very Good \\
\hline
\end{tabular}

In table 8 it can be seen that the coach has implemented a preventive strategy with the periodization method which is $100 \%$ in the very good category, monitoring of exercise and recovery of $81.3 \%$ is in the very good category, sleep is $64.29 \%$ in the category good, hydration and nutrition of $54.17 \%$ were in the sufficient category, communication was $100 \%$ in the very good category, and education was $100 \%$ in the sufficient category.

Table 9. Differences in the average value of knowledge and prevention in athlete and coach

\begin{tabular}{cccccc}
\hline \multicolumn{2}{l}{ Comparison of } & Min & Max & Mean & Category \\
\hline \multirow{2}{*}{ Athletes } & Knowledge & 72 & 92 & 84.67 & Very Good \\
& Prevention & 35.90 & 69.23 & 56.41 & Fair \\
\hline \multirow{2}{*}{ Coach } & Knowledge & 76 & 84 & 80 & Good \\
& Prevention & 74.36 & 76.92 & 75.64 & Good \\
\hline
\end{tabular}

In table 9 it can be seen that there are significant differences in the value of knowledge and prevention in athletes, namely 28.19. While the difference in the value of knowledge and prevention of overtraining in the coaches is 4,36. Although the results of the coach value did not differ significantly, did indicate that the level of prevention of overtraining was coaches slightly lower than knowledge. Based on the data in table 9, to determine whether there is a significant difference or not, a comparison test will be carried out.

Table 10. Data normality test

\begin{tabular}{ccccc}
\hline Kolmogorov-Smirnov $^{\mathbf{a}}$ & & & & \\
\hline & Sthlete & Statistic & df & Sig. \\
Knowledge Outcomes & , 208 & 12 &, 159 \\
\hline
\end{tabular}




\begin{tabular}{lccrc}
\hline \multirow{3}{*}{ Prevention Results } & Coaches &, 260 & 2 & $\cdot$ \\
& Athlete &, 168 & 12 &, 200 \\
& Coaches &, 260 & 2 &. \\
\hline
\end{tabular}

In table 10 , it can be seen that the significance value of athlete's knowledge $(0.159)$ and athlete's prevention $(0.200)$, then the two data indicate that the knowledge and prevention of athletes are normally distributed because the Sig value is $>0.05$. So that for the different tests using the Independent T-Test which will be explained in table 11.

While the significance value of the coaches' knowledge and prevention is unknown, it can be concluded that the two coaches' data are not normally distributed, due to the small number of samples. So that for the different tests using the Mann-Whitney Test which will be explained in table 13.

Table 11. Difference and homogeneity

\begin{tabular}{ccc}
\hline Test of Difference and Homogeneity of & & \\
\hline Variables & $\begin{array}{c}\text { Independent T-Test } \\
(\mathrm{P})\end{array}$ & $\begin{array}{c}\text { Levense Test } \\
(\mathrm{P})\end{array}$ \\
\hline $\begin{array}{c}\text { Knowledge and Prevention of } \\
\text { Athletes }\end{array}$ & 0.000 & 0.020 \\
\hline
\end{tabular}

In table 11 it can be It is known that the results of the test for the difference in knowledge and prevention of athletes are 0,000 . It can be interpreted that there is a significant difference between knowledge and prevention of athletes because of the P-value $<0.05$. The table also shows the results of the homogeneity test, namely 0.020 , which indicates that the data is not homogeneous, because of the P-value $<0.05$.

Table 12. Homogeneity test

\begin{tabular}{|c|c|c|c|}
\hline \multicolumn{4}{|c|}{ One Way Anova } \\
\hline & $\mathrm{F}$ & Sig. & \\
\hline Knowledge and Prevention of Coach & 1.078 & & , 408 \\
\hline
\end{tabular}

The results of the homogeneity test in table 12 show a value of 0.408 , which means that the coach's knowledge and prevention are homogeneous because the P-value is> 0.05.

Table 13. Comparison test of

\begin{tabular}{cccc}
\hline & Maan-Whitney Test & \\
Comparison of & & Sig. (2-tailed) & \\
\hline Knowledge and Prevention of & Athletes & .000 \\
\cline { 2 - 3 } & Coach & .439 \\
\hline
\end{tabular}

Based on the results of homogeneity in table 11, shows that the knowledge and prevention data of athletes are not homogeneous. So to strengthen the data, a non-parametric test was carried out with the Maan-Whitney Test. The results of the comparison test in table 13 show that there is a significant difference in the knowledge and prevention of athletes $(0.000)$ because 
of the P-value $<0.05$. Meanwhile, the comparison between the knowledge and prevention of coach (0.439) did not have a significant difference, because the $\mathrm{P}$ value $>0.05$.

\section{Discussion}

Sports achievement is a sports activity that is competitive and rigorous to achieve victory through competition. Because of its very competitive nature, athletes must prepare themselves optimally, both physically, technically, tactically, and mentally. So all of that must be properly trained and maintained during training or matches through the role of a coach [10]. Basketball is a form of sports achievement that demands a competitive role as a description of sports achievement in general. So that to achieve victory in the game of basketball requires good teamwork, and every athlete is required to be able to perform basic basketball techniques perfectly, and must have the optimal physical condition [11].

Most coaches improve athlete performance by increasing training load and training frequency. However, when the results of training or match results are worse, the coach's natural reaction is that they will still increase weight training [12]. [13] have the same opinion, namely that when an athlete sacrifices most of his life in sports for his career success, the athlete will have high ambition so that the athlete will increase his training hours, with the hope of improving performance and achieving much better results. However, when expectations do not match expectations, it will be a factor in the occurrence of stress.

Doing excessive training continuously and not giving enough time for recovery, will trigger overtraining and can cause athletes to experience physical and mental fatigue [14]. Also, overtraining is caused by several factors, namely stress due to exercise, academic stress, environmental stress, parental demands, and psychological disorders of athletes [6]. With this, if athletes experience an imbalance between stress due to exercise or stress not due to prolonged training, coupled with a lack of good nutritional intake, then athletes can experience fatigue, decreased performance, and symptoms of overtraining others [15].

Signs or symptoms experienced by athletes during condition overtraining according to [16] is divided into 2 kinds of physiological symptoms and psychological symptoms. Physically, athletes will experience an increase in resting heart rate, changes in normal blood pressure, excessive weight loss, excessive thirst, obstructed respiration, digestive disorders, and muscle aches. While the symptoms of overtraining psychological, athletes will experience sleep disturbances, depression, emotional and motivation imbalance, loss of self-confidence, easily drowsy or tired, and decreased appetite.

Athletes and coaches are required to know and understand what signs or symptoms are during the condition of overtraining. If athletes and coaches know the symptoms or signs of overtraining, they will make these symptoms a warning sign [13]. So that athletes and coaches do not let the symptoms get worse. Because with the onset of symptoms of overtraining that is left untreated, it will become a symptom that gets worse and will hurt the condition of the athlete [17].

The impact of overtraining is that athletes will experience prolonged chronic fatigue, resulting in decreased performance and decreased immunity, and athletes will be prone to injury or even early retirement from sports. Based on the results of the research, it shows that the level of knowledge of athletes about overtraining is very good, so according to the theory of [18] it can be interpreted that athletes are ready to compete with other athletes to win in a match. 
Meanwhile, the coach's knowledge about overtraining was in a good category. By the existing theory, it is said that a coach who has a good level of knowledge will have a positive impact on the quality of training. Because the coach will provide a training program following the principles of training and adapted to the condition of the athlete [19]. If the coach's knowledge is not good, the training is likely based on past skills and knowledge [2]. So that it can cause errors in giving weight or training intensity. This can lead to overtraining and at a bad risk for the athlete's condition during the process of achieving sports achievement [20].

Therefore, athletes and coaches must implement a good prevention strategy, to minimize the incidence of overtraining. In general, the prevention of overtraining is based on selfdiscovery over a long period through endurance training and a combination of the knowledge of athletes, coaches, researchers, and sports medicine experts [5].

The results of this research data provide strong evidence that even though athletes and coaches have a good level of knowledge of overtraining, it will be useless if it is not balanced with the application of good prevention of overtraining. This will put the athlete's career at risk. Therefore, good knowledge and prevention of overtraining are needed so that athletes can train optimally in safe conditions. The prevention strategies Overtraining that can be done by athletes and coaches according to Carter et al [6] is divided into several best methods, which include:

\subsection{Periodization}

To prevent overtraining, it can be done by making an exercise program that is progressive and systematic, wherein in the training program there is no sudden increase in intensity or volume, avoiding giving high volumes in a row, increase the variety of exercises so as not to be monotonous, and certainly provide a sufficient recovery period. If it is needed, it can be done by creating an individual training program for each athlete [21].

\subsection{Exercise monitoring}

In addition to making a proper training program, carrying out detailed training monitoring can also help coaches know the condition of their athletes, both in conditions of recovery, stress, even when athletes are injured [22].

To carry out exercise monitoring can be through physiological and psychological monitoring. Biological monitoring can take into account the intensity of exercise and the recovery period by measuring VO2Max, heart rate, and body weight. Also, the RPE session can also be used as consideration for exercise intensity because it can detect the buildup of fatigue experienced by athletes within several days of training [23].

Meanwhile, psychological monitoring can use subjective assessment through several questionnaires that have been validly used in previous research. According to Kusuma [24] the Wellness Questionaire is proven to be able to help coaches and athletes in monitoring fatigue, especially in team sports. [13] Agung \& Tirtayasa in conducting psychological monitoring of athletes using the RESTQ (Recovery Stress Quostionaire for Athletes) questionnaire aims to measure the mental, emotional and physical condition of athletes.

\subsection{Recovery}

The principal cause of overtraining is an imbalance between training and recovery. So with athletes doing a good recovery, they can restore the body's metabolic function so that they can return to a more prime condition so that athletes can show their best performance [25]. To restore 
the body's condition, it can be done in many ways, including massage, compressed garments, thermotherapy, cryotherapy [26].

The purpose of massage is to help improve blood circulation and repair damaged muscles to recover caused by exercise [27]. Massage can also increase the happiness hormone or endhorphins, release tension and relax muscles and increase joint reach [28].

The use of compressed garments is becoming more and more popular, and many people use them during exercise. However, there is evidence that use after exercise can aid recovery and reduce blood lactate concentrations and muscle soreness [29].

Using thermotherapy as recovery can generate sweat to eliminate levels of toxins in the blood, and can increase blood flow to relieve muscle tension [30]. It is recommended to do thermotherapy or steam bath at a temperature of 36 degrees Celsius for 8 to 10 minutes.

Cryotherapy or cold therapy plays an important role in post-workout recovery because it can reduce spasms or muscle damage due to exertion. This cold therapy should not be done for too long, it is good that it is 5-10 minutes [31].

\subsection{Sleep}

Sleep is vital when athletes do intense exercise because lack of sleep will hurt the quality of the training session. The results showed that the application of sleep to athletes was in the poor category, so the athlete may experience impaired cognitive function, especially in the ability to concentrate, and can increase fatigue. Therefore, sleep is one of the best and most effective recovery strategies [32].

A good sleep duration recommendation for athletes, in general, is 7-9 hours per day. [32] advises athletes to take a 30-minute nap during training and in a competitive environment, especially in athletes who experience sleep deprivation.

A person will wake up feeling refreshed and fit if he sleeps for the right duration [33]. Reinforced by the results of research by Mah et al [34] showing that the men's basketball athletes at Stanford University experienced a significant increase in performance after prolonging sleep habits. The athlete also reported prolonged sleep habits, which reduce drowsiness and fatigue.

\subsection{Nutrition and hydration}

In general, nutrition is very important in the recovery period of athletes after training or competition. Because with adequate nutrition, it can help improve athlete performance, prevent fatigue, increase concentration and strength, and speed up recovery. Each athlete will have different nutritional needs every day because it follows the intensity of the exercise being carried out. In one day, athletes are required to eat no less than three times and still eat breakfast. According to Zahra \& Muhlisin [35] to meet nutritional needs athletes must pay attention to many aspects including calorie needs, macronutrients, time, supplements, and hydration.

Hydration is the adequacy of fluids in the body, while dehydration is the lack of fluids in the body. Dehydration can cause decreased performance, weakness in the body, reduced concentration, decreased muscle work, and head strokes. To avoid dehydration, athletes should drink water without waiting for thirst, consume $400-600 \mathrm{ml}$ of water before training or competition, while when training and competing as much as 100-200 ml of water every 15-20 minutes. According to Ashadi [36], to find out that athletes are hydrated or dehydrated, it can be done by testing the color of urine and weighing the body.

\subsection{Education about overtraining}


As mentioned in the research of Meeusen et al [15], cases of overtraining can vary from 7$64 \%$ and athletes who have experienced overtraining will tend to relapse in the future. Therefore, the coach must guide the athlete by providing direction on how the training program is given, as well as providing information that preventing overtraining can maintain health and can improve performance.

Athletes and coaches can also attend sports-related seminars or training, such as sports nutrition science, training program development, injury management. Also, athletes and coaches can seek information through books, magazines, radio, television, and newspapers, which aim to increase their knowledge [37].

\subsection{Communication between athletes and coaches athletes}

Repeatedly athletes face mood swings caused by developing stress outside of training, triggering overtraining. Therefore, communication between athletes and coaches is very important. Good communication, relationships can prevent overtraining by discussing the decline and development of athletes while training. To help coaches correct and know the limits of their athletes' abilities [38].

Based on the results of the study, it shows that the application of athlete communication is in the poor category, which can cause the loss of communication between athletes and coaches. It is like when the coach gives the athlete's head instructions to get enough sleep, consume nutritious foods, and have adequate water. But the athlete does not do what the coach instructs, it can interfere with the training process. Because according to Pradipta [39] the coaches' duty is as a leader, mentor, monitoring, training program planner. Meanwhile, the athlete's job is to do according to the coach's program, be it an exercise program or a recovery program.

\section{Conclusion and suggestion}

Based on the analysis of research data on the basketball team at the provincial level, it can be concluded that there was a significant difference between the knowledge and prevention values of athletes $(\mathrm{p}<0.05)$. Because the average value of the athlete's knowledge about overtraining is higher than the value of prevention. There is no significant difference between the knowledge and prevention values of the coaches ( $p>0.05)$. Although the average value of prevention of overtraining in the coach is lower than of his knowledge.

Based on the above conclusions, it is hoped that athletes and coaches will apply the results of their knowledge in implementing prevention overtraining properly. Because with good knowledge and prevention of overtraining, it will have a positive impact on the career of athletes in achieving sports achievements both at the regional, national, and international levels.

Acknowledgment. The authors would like to thank the Sports Coaching Education Study Program, Faculty of Sport Science, Universitas Negeri Surabaya for providing funding for this research.

\section{References}


[1] Yasiroh U, Siantoro G. Identifikasi Faktor Penunjang Dan Penghambat Prestasi Bola Basket Putri Di Smkn 1 Boyolangu Kabupaten Tulungagung Mahasiswa Universitas Negeri Surabaya. J Prestasi Olahraga. 2019;(2):1-13.

[2] Ashadi K. Implementasi fisiologi olahraga pada olahraga prestasi. Pertem Ilm ilmu keolahragaan Nas Univeritas Negeri Malang Malang. 2014;59-70.

[3] Abdillah GD, Ashadi K. PEMAHAMAN PELATIH SEKOLAH SEPAKBOLA SE KOTA MADIUN TENTANG PHYSIOLOGICAL ROCOVERY. J Prestasi Olahraga. 2018;3(1):1-8.

[4] HB B, Wahyuri AS. Pembentukan Kondisi Fisik. Rajawali Press; 2019.

[5] Kreher J. Diagnosis and prevention of overtraining syndrome: an opinion on education strategies. Open Access J Sport Med. 2016;7:115-22.

[6] Carter JG, Potter AW, Brooks KA. Overtraining syndrome: causes, consequences, and methods for prevention. J Sport Hum Perform. 2014;2(2):1-4.

[7] Andina M. Implementasi Sistem Telemetry Monitor Detak Jantung Dan Laju Napas Untuk Pencegahan Overtraining Saat Bersepeda Menggunakan Logika Fuzzy. 2018;

[8] Grivas G V. Diagnosis of Overtraining and Overreaching Syndrome in Athletes. Sport Exerc Med Open J. 2018;4(3):74-6.

[9] Setyaningrum DAW. Cedera olahraga serta penyakit terkait olahraga. J Biomedika dan Kesehat. 2019;2(1):39-44.

[10] Ashadi K, Fachri RL, Siantoro G, Kusuma DA, Hariyanto A, Kusuma IDM. Comparison of Knowledge and Hydration Awareness on Adolescent Soccer Athletes. In: Mathematics, Informatics, Science, and Education International Conference (MISEIC 2018). Atlantis Press; 2018. p. 5-8.

[11] Irdyahningtyas N, Wismanadi H. Analisis Daya Tahan Aerobik Dan Anaerobik Pada Atlet Putra Di Unit Kegiatan Mahasiswa Bolabasket Universitas Negeri Surabaya. J Kesehat Olahraga. 2019;7(2):183-8.

[12] Pankanin ES. Overreaching and overtraining syndrome-causes, symptoms, diagnostics and prevention. J Educ Heal Sport. 2018;8(7):424-9.

[13] Agung PG, Tirtayasa K. PREVALENSI NON FUNCTIONAL OVERREACHING DAN OVERTRAINING SYNDROME PADA ATLET KEMPO, LARI, DAN TARUNG DERAJAT PRA PON PROVINSI BALI TAHUN 2015. E-Jurnal Med Udayana. 2018;7(8).

[14] Budiwanto S. Metodologi Latihan Olahraga. Malang: Fakultas Ilmu Keolahragaan Universitas Negeri Malang; 2012. 1-169 p.

[15] Meeusen R, Duclos M, Foster C, Fry A, Gleeson M. Prevention , diagnosis and treatment of the overtraining syndrome : Joint consensus statement of the European College of Sport Science ( ECSS ) and the American College of Sports Medic European Journal of Sport Science Prevention, diagnosis and treat. Eur J Sport Sci. 2012;13(1):1-24.

[16] Batubara FR, Ibrahim EI. Amenorea pada Atlet yang Mengalami Overtraining. Maj Kedokt. 2018;34(2):100-8.

[17] Wahjuni ES. Overtraining. In: Seminar Nasional Keolahragaan dan Workshop Neuromuscular Taping. 2016. p. 1-9.

[18] Pratiwi N, Ashadi K. Tingkat Pengetahuan Tentang Overtraining Pada Atlet Dan Pelatih Klub Atletik Petrogres Kabupaten Gresik. J Prestasi Olahraga. 2018;3(1):1-9.

[19] Oktivianingtyas AG. PENGETAHUAN PELATIH BOLA VOLI PADA PROGRAM LATIHAN BOLA VOLI DI KABUPATEN BANYUMAS. Pend Kepelatihan Olahraga-S1. 2018;7(1).

[20] HB B. Kontribusi fisiologi olahraga mengatasi resiko menuju prestasi optimal. Media Ilmu Keolahragaan J Ilmu Keolahragaan. 2013;3(1):41-5.

[21] Turner A. The science and practice of periodization: a brief review. Strength Cond J. 2011;33(1):3446.

[22] Herpandika RP, Yuliawan D, Rizky MY. The analysis of physical conditions of Puslatkot athletes of Kediri city for" Kediri Emas" in porprov 2019. SPORTIF. 2019;5(2):342-53.

[23] Fusco A, Sustercich W, Edgerton K, Cortis C, Jaime SJ, Mikat RP, et al. Effect of progressive fatigue on session RPE. J Funct Morphol Kinesiol. 2020;5(1):15.

[24] Kusuma DA. Evaluasi Kelelahan Pada Latihan Olahraga. Indones Perform J [Internet]. 2018;2(1):55-60. Available from: http://journal2.um.ac.id/index.php/jko 
[25] Fahmi H, Ashadi K. The Comparation of Sport Massage and Hydrotherapy Cold Water to Physiological Recovery. JUARA J Olahraga. 2019;4(2):196-209.

[26] Halson SL. Recovery techniques for athletes. Sport Sci Exch. 2013;26(120):1-6.

[27] Buwono R, Asim A, Supriatna S. PENGARUH PEMBERIAN MASASE OLAHRAGA SEBAGAI PEMANASAN PASIF TERHADAP DAYA TAHAN CARDIOVASCULAR PEMAIN BOLABASKET SMPN 8 MALANG. J Pendidik Jasm. 2016;25(1):114-22.

[28] Purnomo AMI. Manfaat Swedish Massage Untuk Pemulihan Kelelahan Pada Atlet. J Ef. 2015;(27):1-11.

[29] Lu X, Park N-K, Ahrentzen S. Lighting effects on older adults' visual and nonvisual performance: A systematic review. J Hous Elderly. 2019;33(3):298-324.

[30] Vaile J, Halson S, Graham S. Recovery review: science vs. practice. J Aust Strength Cond. 2010;18(2):5-21.

[31] Harahap DS, Jayadi I. EFEK PERENDAMAN AIR DINGIN TERHADAP FLEKSIBILITAS OTOT HAMSTRING SETELAH MELAKUKAN LATIHAN INTENSITAS TINGGI. J Prestasi Olahraga. 2019;2(4).

[32] Bird SP. Sleep, recovery, and athletic performance: A brief review and recommendations. Strength Cond J. 2013;35(5):43-7.

[33] Andriana LM, Ashadi K. Perbandingan dua jenis olahraga pada pagi dan malam hari terhadap kualitas tidur. J Sport J Penelit Pembelajaran. 2019;5(1):98.

[34] Mah CD, Mah KE, Kezirian EJ, Dement WC. The effects of sleep extension on the athletic performance of collegiate basketball players. Sleep. 2011;34(7):942-50.

[35] Zahra S, Muhlisin. Nutrisi bagi atlet remaja. JTIKOR (Jurnal Terap Ilmu Keolahragaan). 2020;5(1):81-93.

[36] Ashadi K. Pentingnya hidrasi bagi atlet. Surabaya: unipress. 2015;

[37] Ar-rasily OK, Dewi PK. FAKTOR - FAKTOR YANG MEMPENGARUHI TINGKAT PENGETAHUAN ORANG TUA MENGENAI KELAINAN. J Kedokt DIponegoro. 2016;5(4):1422-33.

[38] Sholihah I, Pudjijuniarto. KOMUNIKASI INTERPERSONAL PELATIH TERHADAP MOTIVASI BERPRESTASI ATLET. J Kesehat Olahraga. 2021;09(01):95-104.

[39] Pradipta GD. Gaya Kepemimpinan Pelatih Dalam Meningkatkan Prestasi Olahraga. In: Seminar Nasional [Internet]. 2017. Available from: http://eprints.upgris.ac.id/id/eprint/22 